\title{
Łukasz Wiraszka
}

Uniwersytet Jagielloński

lukasz.wiraszka@uj.edu.pl

ORCID: 0000-0002-3653-5926

\section{PRZEKŁAD NAUKOWY \\ A OBRAZOWANIE:}

BADANIA WSTĘPNE

NAD SUBIEKTYWNYMI ASPEKTAMI

ZNACZENIA W PROZIE NAUKOWEJ

Z WYKORZYSTANIEM KILKU TKUMACZEŃ

TEGO SAMEGO TEKSTU ŹRÓDŁOWEGO

DOI: http://dx.doi.org/10.12775/RP.2021.010

Zarys treści: Artykuł przedstawia badania wstępne nad subiektywnymi aspektami znaczenia w przekładzie tekstu naukowego z wykorzystaniem materiału składającego się z jednego tekstu źródłowego w języku angielskim oraz jego pięciu polskich przekładów. Wyniki analizy semantycznej w kategoriach wymiarów obrazowania Ronalda Langackera - narzędzia stworzonego na potrzeby opisu subiektywnych aspektów znaczenia językowego, lecz dotychczas stosowanego głównie do badania semantycznych "detali" w przekładzie literatury pięknej - pokazuja, że sposób widzenia określonych treści przez autora ulega w przekładzie naukowym różnym wypaczeniom. Wobec niezaprzeczalnej roli przekładu w rozwoju nauki oraz istotnej funkcji subiektywnych elementów tekstu naukowego można sformułować tezę, że koncepcja ekwiwalencji na poziomie obrazowania (Tabakowska 2001) ma uzasadnione zastosowanie również w przekładzie tekstu naukowego.

Słowa kluczowe: przekład naukowy, tekst naukowy, gramatyka kognitywna, wymiary obrazowania, konstrukcja sceny 


\section{Wstęp}

Donieważ tłumaczenie stanowi mentalną działalność człowieka, prowadzącą ostatecznie do stworzenia tekstu dającego wyraz określonej interpretacji (por. Bühler 2002) czy też - w terminach językoznawstwa kognitywnego - doświadczanym przez tłumacza konceptualizacjom, można przyjąć, że czynnik ludzki - rozumiany jako wpływ indywidualnego doświadczenia, wiedzy, zasobów językowych, zdolności poznawczych, a w pewnym stopniu także osobowości oraz aktualnego stanu emocjonalnego tłumacza - ma niebagatelny wpływ na odbiór treści wyrażonych w tekście źródłowym oraz sposób ich językowego przedstawienia w tekście docelowym - również w przypadku przekładu tekstów naukowych ${ }^{1}$.

Do fundamentalnych cech stylu przypisywanego tradycyjnie tekstom naukowym zalicza się obiektywność i bezosobowość (por. Gajda 1982: 112-113), jednakże dyskurs naukowy coraz częściej przyciąga uwagę badaczy językowych wyznaczników subiektywności i, w efekcie, coraz więcej badań pokazuje, że publikacje naukowe są $\mathrm{w}$ istocie dalekie od obiektywnego opisu rzeczywistości (np. Gray, Biber 2012: 23-24; Hyland 2005: 173; Hyland 2014: 100; por także Duszak 1994: 296). Tekst naukowy nie jest więc sprawozdaniem ograniczającym się do suchych faktów, zawiera bowiem rozmaite elementy wskazujące na nastawienie autora tekstu (badacza) oraz sygnalizujące dokonywaną przez niego subiektywną ocenę relacjonowanych treści, a także elementy, za pomocą których podejmuje on interakcję z czytelnikiem i angażuje go w swój wywód naukowy, czego nadrzędnym celem jest realizacja funkcji perswazyjnej. Jak przekonuje Marc Silver (2003: 362), dyskurs naukowy ma charakter „zasadniczo perswazyjny”, a formułowane przez naukowców twierdzenia „nigdy nie są po prostu kwestią faktów” (tłumaczenie własne). Wymienione powyżej czynniki leżące po stronie tłumacza oraz obecność w przekazie naukowym elementów subiektywnych, czyli takich, które nie wyrażają faktów, lecz sposób ich widzenia przez opisującego je człowieka, skłaniają do przypuszczenia, że tekst naukowy jest podatny na różnego rodzaju zmiany semantyczne w tłumaczeniu. Jeżeli nawet założyć, że treści obiektywne, tzn. odnoszące się do określonego stanu rzeczy, są w przekładzie naukowym zachowane, można podejrzewać, że sposób

1 Publikacja powstała w ramach realizacji projektu badawczego o numerze 2019/03/X/ HS2/00290 finansowanego przez Narodowe Centrum Nauki. 
przedstawienia tych treści - zwłaszcza w związku z możliwością przyjmowania wobec nich odmiennych punktów widzenia - podlega w tłumaczeniu rozmaitym przesunięciom, których zbadanie może rzucić nowe światło na rzeczywisty charakter komunikacji naukowej w przekładzie - odgrywającym przecież niebagatelną rolę w rozwoju nauki (por. Kozłowska 2007: 13).

Celem badań przedstawionych w niniejszym artykule jest wstępna próba ukazania charakteru zmian w zakresie subiektywnych aspektów znaczenia występujących w tłumaczeniu tekstu naukowego. W części pierwszej przedstawiona zostanie metodologiczna koncepcja przeprowadzonych badań, a także zarys kluczowych dla nich założeń językoznawstwa kognitywnego. Część druga przyniesie analizę jakościową obejmującą 20 przykładów z badanego materiału, której celem jest zilustrowanie zidentyfikowanych w nim odmiennych typów zjawisk semantycznych, a także ich opis w kategoriach aparatu pojęciowego gramatyki kognitywnej. Następnie przedstawione zostaną wnioski oraz dane liczbowe dotyczące poszczególnych typów odnotowanych zjawisk. Artykuł zakończy krótkie podsumowanie.

\section{Metodologia}

W celu udzielenia odpowiedzi na pytanie o naturę przesunięć w zakresie subiektywnych aspektów znaczenia w tłumaczeniu tekstu naukowego zgromadzono zbiór danych obejmujący tekst artykułu naukowego z dziedziny psychologii zdrowia opublikowany oryginalnie w języku angielskim (Marks 2014) oraz pięć jego polskich przekładów, wykonanych niezależnie przez tłumaczy z różnych agencji tłumaczeniowych oferujących usługi w zakresie tłumaczeń specjalistycznych, $w$ tym naukowych. Idea wykorzystania takiego materiału badawczego wynikała $\mathrm{z}$ następującego założenia: jeżeli w tłumaczeniu tekstu naukowego następują zmiany w sposobie ujęcia określonych treści wynikające nie tylko $\mathrm{z}$ nieuchronnych różnic systemowych między językami, ale również ze wspomnianego już czynnika ludzkiego, to najprostszym sposobem ustalenia natury tych zmian będzie porównanie kilku tłumaczeń tego samego tekstu źródłowego wykonanych przez różne osoby. Ponieważ jednak z odmiennymi tłumaczeniami tego samego tekstu można się spotkać głównie w przypadku literatury pięknej, wykorzystanie tej metodologii wiązało się z koniecznością zlecenia przekładów różnym tłumaczom (por. Malmkjaer 1998: 539). 
W uzyskanym w ten sposób materiale wyodrębniono najpierw 164 jednostki zdaniowe tekstu źródłowego, obejmujące tytuł oraz 163 zdania z tekstu właściwego i abstraktu, które następnie zestawiono z odpowiadającymi im fragmentami poszczególnych tłumaczeń (oznaczonych w części 3 symbolami: T1, T2, T3, T4, T5). Z analizy wykluczono fragmenty tekstu zawarte $w$ tabelach, na rysunkach oraz $w$ ich podpisach, a także fragmenty, które w oczywisty sposób wypaczały znaczenie tekstu źródłowego i jako takie należało je uznać za błąd tłumaczeniowy. Celem było uzyskanie materiału badawczego składającego się $\mathrm{z}$ takich fragmentów tekstu oryginału i jego przekładów, które można uznać za odnoszące się do tych samych faktów - czy też, w kategoriach gramatyki kognitywnej, do tej samej sceny pojęciowej - lecz mogące różnić się od siebie sposobem ich przedstawienia, czyli obrazowaniem (ang. imagery), czy inaczej tzw. konstrukcją sceny (ang. construal) ${ }^{2}$. Ponieważ kognitywne pojęcie sceny nie pokrywa się jednak $\mathrm{z}$ żadną z formalnych jednostek podziału tekstu - metafora sceny odnosi się po prostu do treści pojęciowych będących przedmiotem mentalnego oglądu i językowego opisu niezależnie od tego, czy tym opisem jest zdanie, wyraz, fraza, czy nawet pojedynczy morfem - wyodrębnienie z tekstu wszystkich możliwych fragmentów, które wyrażają jakąś scenę skonstruowaną w określony sposób, byłoby zadaniem karkołomnym. W związku z powyższym i z uwagi na wstępny charakter badań podjęto decyzję o uproszczeniu i ujednoliceniu procedury badawczej poprzez skupienie ilościowej analizy porównawczej na tytule oraz fragmentach tekstu zawierających czasownik $\mathrm{w}$ formie osobowej odnoszący się do czynności badawczej (np. The specific studies retrieved were categorized as...; Others such as Taal et al. (1993a) have examined whether...) lub do związanego $\mathrm{z}$ badaniami procesu mentalnego (Periodic re-assessments [...] are deemed highly desirable; no definitive conclusions can be reached) czy też czasownik wyrażający określoną tezę lub wyniki badań (the present findings suggest that...; it is unclear what specific approach is likely to prove optimal; in cases of [...] functional self-efficacy explained the greatest amount of variance in...) wraz z powiązanymi $\mathrm{z}$ nim treściami pojęciowymi, w szczególności treściami symbolizowanymi przez wyrażenia $\mathrm{w}$ funkcji podmiotu i dopełnienia. $Z$ uwagi na fakt, że

2 Choć w najnowszych publikacjach twórca gramatyki kognitywnej Ronald Langacker stosuje wyłącznie termin „konstrukcja sceny”, w niniejszej pracy używam terminu „obrazowanie", aby zachować czytelność nawiązania do wprowadzonego przez Elżbietę Tabakowską (2001) pojęcia ekwiwalencji na poziomie obrazowania. 
w wielu zdaniach tekstu źródłowego można było zidentyfikować więcej niż jeden czasownik wyrażający tezę, wyniki badań bądź czynność badawczą/ mentalną - co wynikało ze złożoności składniowej tekstu - w niektórych przypadkach $\mathrm{z}$ jednej jednostki zdaniowej materiału wyodrębniono kilka osobnych przykładów. Ostatecznie wybrano 229 osobnych przykładów składających się z fragmentu tekstu źródłowego i odpowiadających mu fragmentów polskich tłumaczeń.

Do analizy różnic semantycznych pomiędzy wyodrębnionymi $\mathrm{w}$ ten sposób fragmentami tekstu oryginalnego i tłumaczeń wykorzystano stanowiący jeden $\mathrm{z}$ fundamentalnych elementów gramatyki kognitywnej model wymiarów obrazowania (Langacker 1987: 116 i nast.; 2008: 85 i nast.). Zgodnie z subiektywistycznym podejściem do semantyki (por. Johnson 1987: ix-x; Lakoff 2011: 265 i nast.) oraz wynikającym z niego założeniem o perspektywicznej naturze znaczenia językowego (Cuyckens, Geeraerts 2007: 5) w ujęciu kognitywnym znaczenie wypowiedzi językowych ma charakter konceptualny i obejmuje nie tylko określone treści pojęciowe, ale również sposób ich obrazowania (Langacker 1987), który należy utożsamiać właśnie z subiektywnymi aspektami struktury semantycznej wypowiedzi językowych. Według Ronalda Langackera zdolność obrazowania pozwala użytkownikom języka opisywać tę samą scenę na różne sposoby, a różnice pomiędzy odmiennymi językowymi opisami tej samej sceny - jeśli chodzi o tekst naukowy, taką sceną może być np. hipoteza, określona czynność badawcza, ocena stanu badań czy formułowany przez badacza wniosek można scharakteryzować za pomocą tzw. wymiarów obrazowania (ang. dimensions of imagery/focal adjustments), do których należą: poziom abstrakcji/uszczegółowienia (ang. abstraction/specificity), selekcja (ang. selection), względna wyrazistość poszczególnych treści pojęciowych (ang.prominence), punkt widzenia (ang. viewpoint) oraz subiektywność/obiektywność (ang. subjectivity/objectivity).

W leżącym u podstaw gramatyki kognitywnej modelu sceny (ang. stage model) kluczową rolę odgrywa podmiot dokonujący mentalnego oglądu określonych treści pojęciowych, czyli tzw. konceptualizator (ang. conceptualizer), a znaczenie utożsamiane jest $\mathrm{z}$ konceptualizacją, rozumianą jako całokształt doświadczenia mentalnego związanego $\mathrm{z}$ określoną wypowiedzią językową (Langacker 1987: 5). W zależności od posiadanej wiedzy i przyświecających mu celów komunikacyjnych konceptualizator może dokonywać mentalnego oglądu danej sceny z różnych miejsc i odległości, 
co wpływa na subiektywne aspekty znaczenia ujmowane, odpowiednio, w kategoriach punktu widzenia oraz poziomu abstrakcji/uszczegółowienia (Langacker 2009: 85). Może on ponadto kierować swoją uwagę jedynie na określone fragmenty sceny (selekcja) i koncentrować się na pewnych jej elementach bardziej niż na innych (wyrazistość). Znaczenie wyrażeń językowych zależy również od tego, czy konceptualizator stara się przyjmować rolę niezaangażowanego w oglądaną scenę obserwatora, czy też w pewnym stopniu angażuje się w obserwowaną scenę lub wręcz na nią wkracza (subiektywność/obiektywność).

Poniżej omówione zostaną przykłady odnotowanych w badanym materiale zmian w obrębie wymienionych wymiarów obrazowania. Przykłady ilustrujące różnice $\mathrm{w}$ zakresie selekcji i wyrazistości zostaną ujęte razem w części 2.2 z uwagi na fakt, że wyrazistość jest wymiarem obrazowania $\mathrm{w}$ dużej mierze zależnym od selekcji.

\section{Analiza}

Porównawcza analiza semantyczna wykazała, że przypadki braku ekwiwalencji na poziomie poszczególnych wymiarów obrazowania występują we wszystkich pięciu tłumaczeniach tekstu źródłowego. Zidentyfikowane zmiany pod względem wymiarów abstrakcji/uszczegółowienia, selekcji i wyrazistości, punktu widzenia oraz subiektywności/obiektywności prowadzą, z jednej strony, do różnic w zakresie subiektywnych aspektów znaczenia pomiędzy tekstem oryginalnym a jego przekładem - co potwierdza podejrzenie o podatności tekstu naukowego na zmiany semantyczne w procesie przekładu, z drugiej zaś - do różnic znaczeniowych pomiędzy poszczególnymi tłumaczeniami - co potwierdza hipotezę dotyczącą wpływu indywidualnych cech poznawczych i osobowościowych tłumacza na konceptualizację oraz sposób przedstawienia treści wyrażonych w oryginale.

\subsection{Poziom abstrakcji/uszczegółowienia}

Poziom abstrakcji/uszczegółowienia, czy też krócej: uszczegółowienie, jest wymiarem obrazowania odnoszącym się do precyzji, z jaką opisywane są określone treści pojęciowe (Langacker 2009: 85). Jedną i tę samą scenę można 
opisać bardziej lub mniej szczegółowo, a w przypadku mniej szczegółowego, czyli bardziej ogólnego, opisu można mówić o jego schematyczności w stosunku do opisu zawierającego więcej detali. W przeanalizowanym materiale zidentyfikowano szereg przypadków, w których jedno z tłumaczeń niesie ze sobą mniej szczegółów niż pozostałe, czego przyczyną jest zazwyczaj zastosowanie w procesie przekładu techniki pominięcia jakiegoś elementu tekstu źródłowego lub techniki generalizacji, czyli zastosowania w przekładzie ekwiwalentu o znaczeniu bardziej ogólnym niż dane wyrażenie w oryginale (por. np. Baker 1992: 26). Zjawisko to dobrze ilustruje następujący przykład, w którym tłumaczenie (T4) mówi o „czynniku rzutującym na zachowanie”, podczas gdy inne tłumaczenia, np. (T3) i (T5), informują o „mediacji” bądź nazywają omawiane pojęcie „mediatorem”:

PRZYKŁAD 1

Bandura (1977) proposed that the psychological variable of self-efficacy [...] was a significant mediator of behavior.

[...] odgrywa istotną rolę w mediacji zachowania ${ }^{3}$.

[...] jest istotnym czynnikiem rzutującym na zachowanie.

[...] stanowi istotny mediator zachowania.

Pomimo że tłumaczenie (T4) jest tutaj zgodne z tekstem oryginalnym oraz innymi tłumaczeniami pod tym względem, że można je uznać za odnoszące się do obiektywnie tej samej sytuacji, sposób, w jaki przedstawia ono przedmiotowe pojęcie, jest bardziej schematyczny niż opisy z tłumaczeń (T3) czy (T5), ponieważ te ostatnie - podobnie jak angielski oryginał - określają opisywaną sytuację w sposób bardziej szczegółowy, odnosząc się do konkretnego typu zmiennej niezależnej, jaką jest mediator/zmienna mediująca, czyli zmienna pośrednicząca, co niesie ze sobą dodatkowe informacje na temat specyfiki omawianego w tym fragmencie wpływu czy też „rzutowania” (por.

3 Polskie tłumaczenia przedstawiono w zakresie ograniczonym do fragmentów ilustrujących omawiane zjawisko. Relewantne elementy tekstu zostały pogrubione. 
Bedyńska et al. 2013: 26). Co istotne, kolejne fragmenty tekstu pokazują, że omawiane tu uogólnienie nie jest przypadkiem odosobnionym, albowiem w dalszych partiach tłumaczenia (T4) relacja mediacji/pośredniczenia między omawianą zmienną niezależną a zmienną zależną przedstawiana jest również w sposób bardziej schematyczny niż w pozostałych czterech tłumaczeniach:

PRZYKŁAD 2

self-efficacy also clearly mediates the relationship between...

[...] jest również wyraźnym czynnikiem pośredniczącym między...

[...] poczucie własnej skuteczności wyraźnie rzutuje również na...

[...] wyraźnie pośredniczy również w...

Widać tu zatem konsekwentne stosowanie techniki generalizacji w tłumaczeniu (T4). Oczywiście, przyczyny widocznej tu tendencji można by teoretycznie upatrywać w mniejszych kompetencjach tłumacza odpowiedzialnego za wykonanie tłumaczenia (T4), jak jednak pokazują inne przykłady, przypadki niższego stopnia uszczegółowienia opisywanych treści można odnotować we wszystkich przeanalizowanych przekładach. I tak, podczas gdy tłumaczenie (T1) w przykładzie 3 informuje jedynie ogólnie o „związku”, pozostałe tłumaczenia, np. (T5), opisują ten związek równie szczegółowo co tekst źródłowy, tj. jako „konsekwentną korelację liniową":

PRZYKŁAD 3

The strength of an arthritis patient's self-efficacy perceptions also consistently correlates with measures of functional status in a linear manner

[...] ma związek z $[\ldots]$

[...] koreluje również konsekwentnie w sposób liniowy z [...] 
Z kolei w przykładzie 4 to właśnie tłumaczenie (T5) zawiera mniej szczegółów niż oryginał i pozostałe jego tłumaczenia, ponieważ pomija przymiotnikowy opis (integrated „zintegrowany") typu omawianego w tekście programu edukacji zdrowotnej:

PRZYKŁAD 4

Piyakhachornrot et al. (2011) who developed an integrated health education program [...] showed positive results in a recent quasi experimental study.

$(\mathrm{T} 1, \mathrm{~T} 2, \mathrm{~T} 3, \mathrm{~T} 4)$

[...] którzy opracowali zintegrowany program edukacji zdrowotnej [...]

[...] opracowując program edukacji zdrowotnej [...]

W badanym materiale można też znaleźć przypadki, w których co najmniej jedno z tłumaczeń jest bardziej szczegółowe niż sam tekst źródłowy. Dobrym tego przykładem jest sam tytuł tekstu, który we wszystkich polskich przekładach został w mniejszym lub większym stopniu uszczegółowiony:

PRZYKŁAD 5

Self-efficacy and arthritis disability

Poczucie własnej skuteczności a niepełnosprawność w wyniku zapalenia stawów

Poczucie własnej skuteczności a niepełnosprawność z powodu zapalenia stawów

Własna skuteczność a upośledzenie spowodowane zapaleniem stawów

Poczucie własnej skuteczności a niepełnosprawność w przebiegu zapalenia stawów 


\section{(T5)}

Poczucie własnej skuteczności i niepełnosprawność w zapaleniu stawów

Pomijając inne różnice pomiędzy tymi tłumaczeniami, zauważmy, że każde z nich na swój sposób uszczegóławia angielskie wyrażenie arthritis disability, które nie precyzuje relacji pomiędzy „niepełnosprawnością” (disability) a „zapaleniem stawów” (arthritis) - jej interpretacja wymaga odwołania się do wiedzy pozajęzykowej i wobec tego można ją uznać za przykład ambisemii (por. Kiklewicz 2008: 69-70). Naturalnie, wyższy poziom uszczegółowienia w każdym z pięciu tłumaczeń w stosunku do tekstu oryginalnego wynika tu z różnic między językiem źródłowym a językiem docelowym: ponieważ gramatyka języka polskiego nie dopuszcza możliwości stworzenia równie ambisemicznej, skondensowanej i semantycznie niekompozycyjnej konstrukcji typu [rzeczownik] + [rzeczownik], tłumacz zmuszony jest w takich przypadkach do zastosowania ekwiwalentu uszczegóławiającego wyrażenie z tekstu źródłowego. Co jednak istotne, konieczność dokonania interpretacji wyrażenia źródłowego, a także rozmaite składniowo-leksykalne możliwości jej sformułowania w języku docelowym sprawiają, że tłumaczenia w przykładzie 5 są nie tylko bardziej jednoznaczne niż ich ekwiwalent $\mathrm{z}$ tekstu źródłowego, ale także różnią się od siebie w kategoriach omawianego tu wymiaru obrazowania: z jednej strony tłumaczenia (T4) i (T5) nie niosą informacji o związku przyczynowo-skutkowym, z drugiej natomiast tłumaczenia (T1), (T2) i (T3) dopuszczają interpretację, którą wykluczają pozostałe dwa przekłady, a mianowicie następstwo czasowe pomiędzy zapaleniem stawów a niepełnosprawnością.

\subsection{Selekcja i wyrazistość}

Szczególnie istotne z punktu widzenia tematu naszych rozważań zastosowanie Langackerowskich wymiarów selekcji i wyrazistości dotyczy wyboru na potrzeby komunikacji językowej określonych elementów procesu (tj. zdarzenia, stanu, zjawiska itp.). Jak zauważa Langacker:

Kodowanie językowe charakteryzuje się dużą selektywnością. Konceptualizowane zdarzenie obejmuje zwykle skomplikowaną sieć interakcji pomiędzy licznymi obiektami, z których każdy może potencjalnie zostać 
zobrazowany jako uczestnik [tego zdarzenia], jednakże jedynie niewielka część tych interakcji i uczestników jest wyrażona explicite, a jeszcze mniej ukazywanych jest jako wyraziste (Langacker 2002: 213-214; tłumaczenie własne).

Dyskurs naukowy nie jest pod tym względem wyjątkiem: autor tekstu naukowego wybiera na potrzeby komunikacji jedynie określone elementy zdarzenia (czy szerzej: sytuacji), do którego się odnosi, pomijając jednocześnie pozostałe obiekty i interakcje. Ważną konsekwencją tej selekcji jest to, że treści pojęciowe, które zostały wybrane na potrzeby konstrukcji danej sceny i zyskały bezpośredni wyraz w tekście, w oczywisty sposób nabierają w komunikacie większej wyrazistości niż obiekty i interakcje pominięte, nawet jeśli uczestnictwo tych ostatnich pozostaje $\mathrm{w}$ omawianej $\mathrm{w}$ danym przypadku sytuacji w jakiś sposób domniemane.

Rozważmy w tym kontekście następujący przykład z badanego materiału, porównując tłumaczenia (T2), (T3) i (T4) z tłumaczeniami (T1) i (T5):

PRZYKŁAD 6

Furthermore, cognitive-behavioral interventions [...] are found to enhance arthritis self-efficacy with respect to mood and fatigue, physical capacity, pain, disability, and function (Keefe et al. 1996; Lorig et al. 1989; Smarr et al. 1997; Stenstrom 1994).

Ponadto interwencje kognitywno-behawioralne [...] wzmacniają poczucie własnej skuteczności w walce z zapaleniem stawów w odniesieniu do nastroju i zmęczenia, sprawności fizycznej, bólu, niepełnosprawności i funkcjonowania (Keefe i in., 1996; Lorig i in., 1989; Smarr i in., 1997; Stenstrom, 1994).

Ponadto stwierdzono, że interwencje kognitywno-behawioralne [...] wzmacniają poczucie własnej skuteczności wobec zapalenia stawów w odniesieniu do nastroju i zmęczenia, wydolności fizycznej, bólu, niepełnosprawności i funkcjonowania (Keefe i in., 1996; Lorig i in., 1989; Smarr i in., 1997; Stenstrom, 1994). 
(T3)

Ponadto stwierdzono, że interwencje poznawczo-behawioralne [...] zwiększają własną skuteczność osób z zapaleniem stawów w odniesieniu do nastroju i zmęczenia, możliwości fizycznych, bólu, niepełnosprawności i funkcji (Keefe i in., 1996; Lorig i in., 1989; Smarr i in., 1997; Stenstrom, 1994).

Ustalono również, że interwencje poznawczo-behawioralne [...] wzmacniają poczucie własnej skuteczności w zapaleniu stawów w zakresie nastroju i zmęczenia, sprawności fizycznej, bólu, niepełnosprawności i funkcjonowania (Keefe i wsp., 1996; Lorig i wsp., 1989; Smarr i wsp., 1997; Stenstrom, 1994).

Ponadto interwencje kognitywno-behawioralne [...] zwiększają poczucie własnej skuteczności w zakresie zapalenia stawów w odniesieniu do nastroju i zmęczenia, zdolności fizycznych, bólu, niepełnosprawności i funkcji (Keefe i wsp., 1996; Lorig i wsp., 1989; Smarr i wsp., 1997; Stenstrom, 1994).

O ile w tekście źródłowym oraz w tłumaczeniach (T2), (T3) i (T4) poprawa poczucia własnej skuteczności w wyniku interwencji poznawczo-behawioralnych ukazana jest jako ustalenie dokonane w szeregu badań naukowych (are found to enhance „stwierdza się, że poprawiają”; „stwierdzono, że [...] wzmacniają"; „stwierdzono, że [...] wzmacniają”; „ustalono również, że [...] wzmacniają"), o tyle w tłumaczeniach (T1) i (T5) to samo zjawisko przedstawione jest jako fakt, ponieważ proces dokonywania ustalenia naukowego został w nich pominięty. Pomimo że w nawiasie na końcu zdania zachowano odsyłacze do publikacji z badaniami potwierdzającymi opisane zjawisko, z punktu widzenia konstruowanego przekazu rola tych badań jest w tym przypadku co najmniej drugoplanowa, jeśli nie jedynie domniemana, podczas gdy w angielskim oryginale oraz przekładach (T2), (T3), (T4) jest ona wyeksponowana jako kluczowy proces konceptualizowanej sceny, a więc element o dużej wyrazistości.

Z podobną sytuacją mamy do czynienia w przykładzie 7, gdzie na centralny element sceny opisanej w tekście źródłowym wybrany został przez konceptualizatora proces dokonywania oceny przez badaczy (are deemed „są uznawane/uważane"): 
PRZYKŁAD 7

Periodic re-assessments and a long-term, rather than a short-term, therapeutic relationship are deemed highly desirable in this respect

W tym względzie za szczególnie pożądane uznaje się przeprowadzanie okresowych ocen

Okresowa kontrola oraz [...] jest w tym kontekście bardzo korzystna

Jak jednak łatwo zauważyć, przedstawione powyżej dwa tłumaczenia różnią się od siebie pod względem selekcji: o ile przekład (T1) - podobnie jak oryginał - wysuwa na plan pierwszy dokonywaną przez badaczy czynność poznawczą, o tyle tłumaczenie (T5) zupełnie ją pomija, czego rezultatem jest przedstawienie opisanego stanu jako faktu.

Kolejny przykład dokonywanej przez konceptualizatora selekcji treści na potrzeby komunikacji językowej dotyczy wyboru jednego z szeregu procesów tworzących złożoną domenę pojęciową związaną z daną interakcją czy zdarzeniem (tzw. skrypt ${ }^{4}$ ) na centralny element konstruowanej sceny (tzw. profil), czego rezultatem jest uwydatnienie wybranego elementu przy jednoczesnym przesunięciu pozostałych na drugi plan (por. Croft, Cruse 2004: 16-17). Przykładem takiego skryptu może być ciąg działań i elementów związanych z pozyskiwaniem grantu na badania naukowe, który w uproszczeniu można by ująć w następujący sposób: badacze starają się uzyskać fundusze na realizację własnych badań, występując z wnioskiem do wybranej instytucji, której członkowie dokonują oceny wniosku i ostatecznie przyznają środki na ten cel lub odmawiają ich przyznania. Zwróćmy uwagę, że językowy opis całego tego ciągu wydarzeń może się skupiać jedynie na wybranych jego elementach, pomijając tym samym pozostałe. Na przykład zdanie „Badaczka starała się o grant” nie zawiera wzmianki o instytucji, w której ubiegano się o grant ani o podjętej ostatecznie decyzji. Co więcej, nie odwołuje się ono również bezpośrednio do badań - w skonstruowanej w ten sposób scenie badania są jedynie elementem domniemanym, wchodzącym w skład tzw. bazy pojęciowej niezbędnej do zrozumienia pojęć BADACZKA

\footnotetext{
4 Zob. Schank, Abelson (1977).
} 
oraz GRANT - przez co pojęcie BADANIA NAUKOWE jest w przypadku konceptualizacji leżącej u podstaw tego zdania aktywowane znacznie słabiej (tzn. jest mniej wyraziste) niż np. pojęcie BADACzKA.

Przypatrzmy się teraz przykładowi 8 . Na scenie opisywanej przez angielski oryginał figuruje pojęcie BADANIA (research), zaprzeczony proces OTRZYMYWAĆ/UZYSKIWAĆ (received) oraz pojęcie GRANT (grant):

PRZYKŁAD 8

This research received no specific grant from any funding agency in the public, commercial, or not-for-profit sectors.

Zauważmy przy tym, że na opisanej w ten sposób scenie nie figurują ani sami badacze, ani też instytucja przyznająca fundusze na badania. Tymczasem wyrazistość tych pierwszych zwiększa się w przekładzie (T3), gdzie agensem procesu uzyskiwać nie jest już (jak w tekście źródłowym) pojęcie BADANIA, tylko schematycznie wyspecyfikowany BADACZ:

Na to badanie nie uzyskano funduszy z żadnego konkretnego grantu...

Oczywiście, zastosowanie czasownika w formie bezosobowej („uzyskano") sprawia, że zdanie nie odnosi się bezpośrednio do autorów tekstu, jednakże aktywna rola czynnika ludzkiego w staraniach o uzyskanie grantu na badania jest tutaj bardziej wyrazista niż w przypadku, gdy agensem procesu uzyskiwać jest pojęcie badania. Inaczej rzecz ujmując, konceptualizator (tj. autor tekstu/badacz) jest w tym przypadku nieco bardziej zobiektyfikowany (patrz część 2.4), tzn. jego rola nie sprowadza się już wyłącznie do roli obserwatora sceny; rezygnacja $\mathrm{z}$ wyboru pojęcia BADANIA na agensa opisywanego procesu i zastosowanie w zamian schematycznego pojęcia BADACZ sprawiają, że konceptualizator staje się (przynajmniej pośrednio) w tę scenę uwikłany, a zatem większej wyrazistości nabiera tu również odpowiedzialność badaczy za nieuzyskanie ewentualnego grantu.

Z odwrotnie skonstruowaną pod tym względem sceną mamy natomiast do czynienia w tłumaczeniach (T2) i (T4):

Na badania te nie została przyznana żadna konkretna dotacja przez żadną $\mathrm{z}$ agencji finansujących... 
(T4)

Na niniejsze badanie nie przyznano jakiegokolwiek specjalnego grantu od jakiejkolwiek instytucji...

W tym przypadku wybór procesu przyznawać sprawia, że większej wyrazistości nabiera rola organizacji finansujących badania naukowe, a jednocześnie na dalszy plan zepchnięta zostaje kwestia ewentualnej odpowiedzialności badaczy za nieuzyskanie grantu. Można też powiedzieć, że w porównaniu z przekładem (T3) tłumaczenia (T2) i (T4) wyrażają przeciwny punkt widzenia $\mathrm{w}$ sensie podobnym do rezultatu procedury modulacji opisanej przez Jeana-Paula Vinaya i Jeana Darbelneta (1957). Ta uwaga prowadzi nas prosto do zmian punktu widzenia $\mathrm{w}$ rozumieniu gramatyki kognitywnej.

\subsection{Punkt widzenia}

Pojęcie punktu widzenia rozumiane jest w gramatyce kognitywnej jako miejsce w określonej domenie poznawczej, z którego konceptualizator dokonuje oglądu sceny, przy czym istotną cechą tego pojęcia jest jego wymiar deiktyczny: punkt widzenia konceptualizatora zaznacza się pośrednio w konkretnych wyrażeniach językowych użytych do opisu danej sceny, czego najprostszym przykładem są choćby zaimki odnoszące się do domeny przestrzeni, np.tu - tam; ten - tamten itd. Jednakże zgodnie z kognitywistycznym zobowiązaniem do generalizacji ${ }^{5}$ pojęcie punktu widzenia - choć termin sam w sobie sugeruje obserwację wzrokową - znajduje również odniesienie do innych, bardziej abstrakcyjnych domen, takich jak domena czasu, domena relacji społecznych, domena wiedzy/stopnia pewności (domena epistemiczna) czy też oceny/wartościowania (domena aksjologiczna) itp., w których to przypadkach można mówić o metaforycznych rozszerzeniach podstawowego, przestrzennego rozumienia punktu widzenia (por. Tabakowska 2004: 49). Przykłady przedstawione poniżej ilustrują zastosowanie $\mathrm{w}$ badaniach nad przekładem pojęcia punktu widzenia w domenie czasu, $\mathrm{w}$ domenie epistemicznej, a także w domenie wartościowania.

\footnotetext{
5 Zob. np. Lakoff (1991).
} 


\subsubsection{Punkt widzenia w domenie czasu}

Czas gramatyczny jako kategoria deiktyczna wskazuje na umiejscowienie konceptualizatora na osi czasu względem czasu wystąpienia lub trwania opisywanej sytuacji. Użycie czasu teraźniejszego sygnalizuje zbieżność wystąpienia konceptualizowanej sceny z czasem wypowiedzi, a przez to - jej aktualność z punktu widzenia osoby mówiącej/piszącej, ewentualnie z punktu widzenia innego konceptualizatora (por. Langacker 1987: 140). Dobrym tego przykładem z materiału poddanego analizie jest następujący fragment angielskiego tekstu źródłowego:

\section{PRZYKŁAD 9}

According to Somers et al. (2010), self-efficacy also clearly mediates the relationship between disease severity and pain and functioning, and in cases of older adults with knee osteoarthritis, functional self-efficacy explained the greatest amount of variance in all physical performance measures as determined by step-wise linear regressions (Maly et al., 2005). In other studies, self-efficacy levels also explained differential disease responses (Bolen et al., 2010)...

$\mathrm{z}$ trzema wystąpieniami czasownika $\mathrm{w}$ formie osobowej: mediates, explained i explained. O ile w przypadku pierwszego z nich użycie czasu teraźniejszego wskazuje na aktualność sformułowanej w zdaniu tezy z punktu widzenia badaczy wymienionych na początku zdania (According to Somers et al. „Według Somers i in.”), o tyle w pozostałych dwóch przypadkach mamy do czynienia z czasem przeszłym sygnalizującym brak zbieżności czasowej, a zatem dystans na osi czasu pomiędzy konceptualizatorem domyślnym (tj. autorem tekstu) a opisywanymi scenami. Innymi słowy, we wszystkich trzech przypadkach autor tekstu dystansuje się od relacjonowanych tez: czy to przypisując punkt widzenia innemu konceptualizatorowi (Somers et al.), czy też formułując je za pomocą czasu przeszłego, a tym samym wskazując na ich aktualność z perspektywy badań relacjonowanych w publikacjach podanych w nawiasie (Maly et al., 2005 oraz Bolen et al., 2010).

Przejdźmy teraz do analizy tłumaczeń. Okazuje się, że aż w czterech z nich, tj. w (T1), (T3), (T4) i (T5), punkt widzenia związany z drugą z wymienionych powyżej tez wyrażonych czasownikiem został przesunięty poprzez zastosowanie w polskim przekładzie czasu teraźniejszego: 
(T1)

[...] w przypadku osób starszych z zapaleniem kostnostawowym kolana poczucie własnej skuteczności funkcjonowania tłumaczy największą zmienność we wszystkich miarach sprawności fizycznej, określaną za pomocą stopniowych regresji liniowych (Maly i in., 2005).

[...] w przypadku osób starszych z chorobą zwyrodnieniową stawu kolanowego funkcjonalna własna skuteczność tłumaczy największą zmienność we wszystkich pomiarach sprawności fizycznej, wyznaczonych metodą stopniowej regresji liniowej (Maly i in., 2005).

...u osób starszych z chorobą zwyrodnieniową stawu kolanowego funkcjonalne poczucie własnej skuteczności tłumaczy najwięcej rozbieżności wśród wszystkich wskaźników sprawności fizycznej ustalonych na podstawie stopniowych regresji liniowych (Maly i wsp., 2005).

[...] w przypadku starszych osób dorosłych z chorobą zwyrodnieniową stawów kolanowych, poczucie własnej skuteczności funkcjonalnej tłumaczy największą zmienność we wszystkich miarach sprawności fizycznej, określaną przez stopniowe regresje liniowe (Maly i wsp., 2005).

W wyniku tego przesunięcia formułowana w tej części tekstu teza została zobrazowana jako aktualna - czyli jako prawdziwa - z punktu widzenia autora tekstu. Co ciekawe, zastosowanie czasu przeszłego w pozostałym tłumaczeniu (T2) również nie wydaje się gwarantować zachowania punktu widzenia wyrażonego w angielskim oryginale („poczucie własnej skuteczności wyjaśniało największą ilość zmienności”), ponieważ niedokonany aspekt polskiego czasownika w czasie przeszłym uwydatnia w tym przypadku brak aktualności omawianej tezy - nawet pomimo odsyłacza do odpowiedniej publikacji w nawiasie $^{6}$ :

6 Publikację wskazaną w nawiasie można tu wręcz uznać za potwierdzenie nieaktualności opisywanej tezy. 
(T2)

[...] w przypadku starszych osób dorosłych z chorobą zwyrodnieniową stawów kolanowych funkcjonalne poczucie własnej skuteczności wyjaśniało największą ilość zmienności we wszystkich miarach sprawności fizycznej wyznaczanych przez krokowe regresje liniowe (Maly et al., 2005). W innych badaniach poziom poczucia własnej skuteczności również wyjaśniał różnice w reakcjach na chorobę (Bolen i in., 2010).

Z nieco inną sytuacją mamy natomiast do czynienia w ostatnim zdaniu tego przekładu („wyjaśniał różnice”), gdzie obecność okolicznika w zdaniu („w innych badaniach”) sprawia, że uwaga konceptualizatora nie skupia się na kwestii zbieżności opisywanej sceny z czasem wypowiedzi (tj. na jej aktualności), lecz na jej zbieżności z ramami czasowymi wyznaczonymi przez okolicznik.

Wyznacznikami temporalnego punktu widzenia mogą być również elementy leksykalne. $Z$ takim właśnie przypadkiem mamy do czynienia w przykładzie 10, gdzie przysłówek użyty w angielskim tekście źródłowym (recently „niedawno/ostatnio") wskazuje, że konceptualizator dokonuje obserwacji opisywanej sceny z punktu na osi czasu zbiegającego się z czasem wystąpienia aktu mowy:

PRZYKŁAD 10

More recently, Hammond and Freeman (2001) extended their ideas to [...]

(T1), (T2), (T3), (T5)

Niedawno, Hammond i Freeman (2001) [...]

W późniejszym okresie Hammond i Freeman (2001) [...]

Konsekwencją przyjęcia „bieżącego” punktu widzenia w czasie jest ukazanie omawianych w zdaniu badań jako bliższych czasom obecnym, co może z kolei przekładać się na przypisanie im wartościowania pozytywnego: badania naukowe przeprowadzone „niedawno” to badania „aktualne”, a często również „nowatorskie”. Podobny punkt widzenia - tzn. taki, który na osi czasu znajduje się w punkcie tożsamym z momentem wystąpienia aktu mowy - odwzorowują tłumaczenia (T1), (T2), (T3) i (T5), w których wystę- 
puje przysłówek „niedawno”: konceptualizator ogląda tu scenę z momentu wyznaczanego przysłówkiem „teraz”. Należy jednak oczywiście zauważyć, że w wymienionych przekładach obserwowana scena znajduje się bliżej konceptualizatora niż w angielskim oryginale, gdzie użycie przysłówka recently w stopniu wyższym zwiększa nieco dystans od „teraz”. Z kolei zastosowane w tłumaczeniu (T4) wyrażenie „W późniejszym okresie” przesuwa punkt widzenia $\mathrm{z}$ chwili obecnej do czasu wcześniejszych badań, opisywanych w poprzednich partiach tekstu: punkt widzenia ulega więc $\mathrm{w}$ tym przypadku przesunięciu $\mathrm{z}$ „teraz” do „wtedy”. Skutkiem tego przesunięcia jest zatarcie (bliskiego!) związku czasowego pomiędzy badaniami omawianymi w zdaniu a chwilą obecną, a przez to również eliminacja możliwości wywołania pozytywnego wartościowania.

\subsubsection{Epistemiczny punkt widzenia}

Domena wiedzy czy też przekonania autora co do prawdziwości formułowanych tez jest jednym z ważniejszych aspektów dyskursu naukowego. Głównym powodem takiego stanu rzeczy jest fakt, że twierdzenia naukowe są najczęściej opatrzone dodatkowymi określeniami wskazującymi na ich pożądaną (z punktu widzenia autora tekstu) interpretację w zakresie stopnia prawdopodobieństwa (Hyland 1998: viii). To czyni epistemiczny punkt widzenia jednym $\mathrm{z}$ kluczowych elementów analizy przekładu tekstu naukowego z perspektywy semantyki subiektywistycznej. Langackerowski punkt widzenia będzie w tym przypadku rozumiany jako pozycja konceptualizatora $\mathrm{w}$ domenie wiedzy względem procesu przedstawionego na scenie, natomiast dystans między nimi należy pojmować jako wyznacznik oceny stopnia pewności: od całkowitego przekonania (bliskość obserwowanej sceny) do poważnych wątpliwości (znaczne oddalenie) ${ }^{7}$.

W przeanalizowanym materiale zidentyfikowano przypadki, w których poszczególne tłumaczenia różniły się od siebie umiejscowieniem punktu widzenia konceptualizatora $\mathrm{w}$ domenie epistemicznej. Rozważmy następujący przykład:

7 Zwróćmy uwagę na istotną w tym względzie korelację z prototypowym, przestrzennym wymiarem kategorii punktu widzenia: im większa odległość od obserwowanego obiektu, tym trudniej jest go rozpoznać. 
PRZYKŁAD 11

prospective studies strongly support the view that $[\ldots]$

Badania prospektywne dowodzą jednak, że [...]

badania prospektywne zdecydowanie potwierdzają pogląd, że [...]

badania prospektywne zdecydowanie popierają pogląd, że [...]

Pomijając ewentualne wątpliwości stylistyczne dotyczące niektórych wyborów leksykalnych w powyższych tłumaczeniach, należy zauważyć, że przedstawiają one różną ocenę prawdziwości sytuacji opisanej w dalszej części tekstu, tj. w zdaniu podrzędnym: od „zdecydowanego popierania”, przez „Zdecydowane potwierdzanie”, po „dowodzenie”.

Z jeszcze większym stopniem rozbieżności pod względem dokonywanej przez autora tekstu oceny epistemicznej opisywanej tezy mamy do czynienia w przykładzie 12, gdzie z jednej strony z tłumaczeń (T2) i (T3) dowiadujemy się o naukowym "potwierdzeniu” przedstawianego dalej stanowiska, $\mathrm{z}$ drugiej zaś tłumaczenie (T4) stawia wiarygodność tego stanowiska pod znakiem zapytania („utrzymuje”). Zwróćmy ponadto uwagę, że w tłumaczeniach (T2) i (T3), podobnie zresztą jak w angielskim oryginale, agensem procesu są „badania Bandury”, co przyczynia się do uwiarygodnienia opisywanej dalej tezy w tym sensie, że potwierdza ją nie badacz - czyli nie człowiek, którego rola schodzi tu na drugi plan i który może być przecież stronniczy lub może się pomylić - tylko „badania”. W tłumaczeniu (T4) agensem jest natomiast sam badacz („Bandura”), co w zestawieniu z czasownikiem „utrzymuje” przyczynia się do ukazania epistemicznej oceny opisywanego stanu rzeczy jako subiektywnej i mało wiarygodnej.

PRZYKŁAD 12

Moreover, Bandura's $(1986 a, 1994)$ research has supported the view that [...]

(T2), (T3)

Co więcej, badania Bandury (1986a, 1994) potwierdziły pogląd, że $[\ldots]$ 
Bandura utrzymuje ponadto w swoich pracach (1986a, 1994), że [...]

Odmienne punkty widzenia pod względem stopnia pewności autora co do formułowanej tezy ilustrują także tłumaczenia w następującym przykładzie:

PRZYKŁAD 13

Consequently, efforts to help optimize self-efficacy for a variety of behaviors are arguably highly salient in efforts to yield more favorable outcomes for people with an arthritic condition than those attained when ignoring such efforts.

[...] są niewątpliwie bardzo ważne $[\ldots]$

[...] są niewątpliwie wybitnie istotne $[\ldots]$

(T4), (T5)

$[\ldots]$ są prawdopodobnie bardzo istotne $[\ldots]$

W tym przypadku odmienna ocena dotyczy wpływu na stan zdrowia pacjentów omawianych w tekście działań zmierzających do poprawy ich poczucia własnej skuteczności i mieści się w zakresie od „prawdopodobnie bardzo istotnego” (T4 i T5), przez „niewątpliwie bardzo ważny” (T1), po "niewątpliwie wybitnie istotny”.

W badanym materiale odnotowano również takie przypadki, w których element wyrażający - zwykle ostrożną - ocenę stopnia pewności co do prawdziwości formułowanej tezy został w przekładzie całkowicie pominięty, w wyniku czego teza sformułowana w tekście docelowym nabiera charakteru kategorycznego sądu opisującego potwierdzony naukowo fakt tak jak w tłumaczeniu (T4) w przykładzie 14:

PRZYKEAD 14

In the counseling domain, the present findings suggest that routinely assessing self-efficacy $[. .$.$] is strongly recommended [...]$ 
(T4)

W obszarze psychoterapii zdecydowanie zaleca się rutynową ocenę poczucia własnej skuteczności [...]

W przykładzie tym angielski tekst źródłowy przedstawia słuszność danych zaleceń terapeutycznych jako prawdopodobny - choć wymagający jeszcze potwierdzenia - wniosek wypływający z przeprowadzonych badań (the present findings suggest ,przedstawione wyniki wskazują, że...”), podczas gdy omawiane polskie tłumaczenie zupełnie pomija odniesienie do wyników badań oraz wyrażaną czasownikiem suggest ocenę ich pewności, ukazując słuszność wspomnianych zaleceń jako bezdyskusyjny fakt.

\subsubsection{Aksjologiczny punkt widzenia}

Wyrażany w tekście naukowym punkt widzenia może również dotyczyć oceny aksjologicznej, tzn. może sygnalizować pozytywne bądź negatywne wartości przypisywane przez konceptualizatora określonym treściom pojęciowym. Przesunięcia aksjologicznego punktu widzenia w badanym materiale omówimy na dwóch przykładach, z których pierwszy (15) ilustruje wprowadzenie do tłumaczenia nieobecnego w tekście źródłowym punktu widzenia pacjenta:

PRZYKŁAD 15

By contrast, arthritis patients with low perceived self-efficacy are likely to experience poor health outcomes, especially excessive pain [...]

Z kolei pacjenci z zapaleniem stawów i niskim spostrzeganiem własnej skuteczności ponoszą ryzyko słabych efektów leczenia, w szczególności nadmiernego bólu [...]

O ile w tekście angielskim mamy do czynienia $\mathrm{z}$ opisem treści prowadzonym z punktu widzenia zewnętrznego wobec pacjentów, a mianowicie z punktu widzenia terapeuty, o tyle użyte w tłumaczeniu (T4) sformułowanie „[pacjenci] ponoszą ryzyko” odzwierciedla punkt widzenia pacjentów: ryzyko, o którym tu mowa, stanowi zagrożenie dla pacjentów. Inaczej rzecz ujmując, 
do tłumaczenia (T4) wprowadzone zostało wartościowanie z punktu widzenia pacjenta, które jest nieobecne w scenie opisanej w angielskim oryginale. Przyjęcie punktu widzenia pacjenta stoi tu w sprzeczności nie tylko z neutralnym pod względem wartościowania orzeczeniem are likely to experience (,istnieje prawdopodobieństwo, że będą doświadczać"), ale również z terminem health outcomes („efekty leczenia”), który - choć poprzedzony wykładnikiem wartościowania negatywnego (poor „słabe/złe”) - odnosi się do zmiany stanu zdrowia pacjenta w wyniku zastosowanej interwencji medycznej (por. Sedgley 2013: 15), a zatem wyraża punkt widzenia terapeuty ${ }^{8}$.

Co ciekawe, tłumaczenie (T4) dostarcza również przykładu ilustrującego wprowadzenie do tekstu wartości pozytywnych niemających swojego wykładnika w tekście źródłowym. Chodzi tu mianowicie o z pozoru nieistotne użycie przyimka „dzięki”:

\section{PRZYKŁAD 16}

Importantly, these observed improvements are likely to be commensurate with those obtained by arthritis medications, while reducing utilization of, and dependency upon, health-care services (Lorig et al., 1993).

Co ważne, obserwowana poprawa ma szansę być współmierna do poprawy uzyskiwanej dzięki lekom stosowanym w zapaleniu stawów [...]

Należy zaznaczyć, że w zdaniu tym porównywane są efekty terapeutyczne - kluczowych z punktu widzenia prezentowanego w tekście wywodu oraz jego głównej tezy - środków niefarmakologicznych z działaniem farmaceutyków. Jak wynika $z$ tekstu źródłowego, efekty te są porównywalne z efektami w zakresie fizycznego funkcjonowania pacjenta, jakie dają środki farmakologiczne, i to właśnie ten fakt, tj. skuteczność środków niefarmakologicznych, ukazywany jest w tekście w świetle pozytywnym (za pomocą przysłówka importantly, a w polskim przekładzie za pomocą wyrażenia „co ważne”). Widać tu więc jednoznaczny zamysł retoryczny, z którym jednak niespójne jest dodatkowe przypisanie w rozpatrywanym tłumaczeniu pozytywnych wartości stanowiącym jedynie punkt odniesienia środkom farmakologicznym.

8 Dziękuję anonimowemu Recenzentowi za zwrócenie uwagi na leksykalny wykładnik wartościowania w omawianym przykładzie. 


\subsection{Subiektywność/obiektywność}

W Langackerowskim modelu sceny i wymiarów obrazowania pojęcia subiektywności i obiektywności odnoszą się do stopnia, w jakim obecność konceptualizatora - czyli podmiotu (subiektu) dokonującego oglądu - zaznacza się w mentalnej scenie konstruowanej na potrzeby komunikacji językowej (Langacker 2005). W sytuacjach, kiedy obecne na scenie treści pojęciowe nie odnoszą się w żaden sposób do konceptualizatora, powiemy, że jest on konstruowany subiektywnie, tzn. odgrywa rolę niezaangażowanego obserwatora. Z kolei w przypadku, gdy obecność konceptualizatora zaznacza się w jakiś sposób na scenie, stwierdzimy, że jest on konceptualizowany bardziej obiektywnie, tzn. w mniejszym lub większym stopniu staje się jednocześnie przedmiotem (obiektem) własnej obserwacji. Skrajnym przypadkiem tzw. zobiektyfikowania konceptualizatora jest sytuacja, w której pojawia się on na scenie w wyniku użycia zaimka ,ja” - wówczas konceptualizator jest nie tylko obserwatorem, ale również obserwowanym obiektem.

Akcentowanie obecności bądź, wręcz przeciwnie, ukrywanie konceptualizatora ma $\mathrm{w}$ dyskursie naukowym istotne znaczenie w przypadkach, gdy konceptualizatorem jest sam autor tekstu, czyli badacz zdający relację z przeprowadzonego procesu badawczego i związanych z nim czynności poznawczych. W takiej sytuacji autor tekstu może, mniej lub bardziej bezpośrednio, odwoływać się do własnej osoby, przyjmując w ten sposób odpowiedzialność/uznanie za opisywane czynności, lub też stosować strategię polegającą na ukrywaniu swojego zaangażowania w opisywane procesy poznawcze, a tym samym usuwać $\mathrm{z}$ pola uwagi czytelnika rolę (podatnego na emocje i pomyłki) czynnika ludzkiego (por. Hyland 1998: 172, a także Hyland 2014: 102).

Z przesunięciem w zakresie subiektywności/obiektywności mieliśmy już do czynienia w przykładzie 8, w którym tekst źródłowy (This research received no specific grant, dosł. „Badania nie otrzymały żadnego konkretnego grantu”) wskazywał na duży stopień zsubiektyfikowania roli autora tekstu/ badacza jako konceptualizatora, podczas gdy jedno z tłumaczeń („Na to badanie nie uzyskano funduszy”) obiektyfikowało jego rolę poprzez użycie czasownika „,uzyskać”, a tym samym uwydatniało odpowiedzialność badacza za nieuzyskanie grantu na przedstawione badania.

Semantyczne różnice w zakresie obiektywności/subiektywności można też przedstawić na przykładzie 17: 
PRZYKŁAD 17

Although no definitive conclusions can be reached [...]

Mimo że nie wyciągnięto żadnych ostatecznych wniosków [...]

Chociaż nie można wyciągnąć ostatecznych wniosków [...]

W angielskim tekście omawiana scena ukazana jest jako ogólny brak możliwości przeprowadzenia procesu poznawczego polegającego na sformułowaniu jednoznacznych konkluzji (no definitive conclusions can be reached „nie da się wyciągnąć jednoznacznych wniosków”). Omawiany proces poznawczy nie jest więc w tym przypadku przypisany do konkretnego agensa, a zatem zaangażowanie autora tekstu w konceptualizowaną tu scenę również pozostaje niewielkie. Przedstawione powyżej dwa polskie przekłady rozpatrywanego fragmentu diametralnie różnią się od siebie pod tym względem: o ile tłumaczenie (T2) zachowuje subiektywność konceptualizatora porównywalną $z$ angielskim oryginałem, o tyle w tłumaczeniu (T1) omawiany proces poznawczy został ograniczony do jednego, konkretnego przypadku, przez co jego domyślnym agensem jest autor tekstu. Należy zatem stwierdzić, że zaangażowanie domyślnego konceptualizatora w opisywaną w tym przekładzie scenę jest znacznie większe niż w przypadku oryginału czy przekładu (T2), a więc mamy tu do czynienia z obiektyfikacją.

Przeciwną zmianę w tłumaczeniu ilustruje przykład 18, w którym użyty w tekście źródłowym czasownik deem („uważać/uznawać”) odnosi się do procesu myślowego, a zatem czynności, której agensem jest człowiek, i w ten sposób wskazuje na pewien stopień zaangażowania konceptualizatora w ocenę opisywanej sceny:

PRZYKŁAD 18

Periodic re-assessments and a long-term, rather than a short-term, therapeutic relationship are deemed highly desirable in this respect [...]

Okresowa kontrola oraz długoterminowa, a nie krótkoterminowa, relacja terapeutyczna jest w tym kontekście bardzo korzystna [...] 
Jak widać, $\mathrm{w}$ przedstawionym powyżej polskim tłumaczeniu brakuje jakiegokolwiek odniesienia do procesu myślowego, a tym samym opisywana tu scena zostaje ukazana jako niezależna od konceptualizatora. Należy tu zatem odnotować całkowite zsubiektyfikowanie konceptualizatora w porównaniu $\mathrm{z}$ angielskim oryginałem, co ma również przełożenie na epistemiczny punkt widzenia, albowiem wynikiem tej zmiany jest jednocześnie ukazanie opisywanej tezy jako bezspornego faktu.

Podobne zjawisko ilustruje przykład 19:

PRZYKŁAD 19

To be included in the present review, only English language publications

[...] were deemed acceptable.

W niniejszej pracy uwzględniono wyłącznie publikacje [...]

Do bieżącego przeglądu włączano wyłącznie prace opublikowane [...]

W tym przypadku czasowniki („uwzględnić” i „włączyć”) użyte w tłumaczeniach (T1) i (T3) nie odnoszą się już bezpośrednio do procesów myślowych, więc nie przywołują one człowieka jako agensa w takim stopniu jak angielski czasownik deem. Z tego powodu rola autora jako domyślnego konceptualizatora jest tutaj również zsubiektyfikowana. Przedstawioną tu sytuację można też opisać w kategoriach wyrazistości: obecność człowieka (w domyśle: autora tekstu) jest bardziej wyrazista w tekście angielskim, ponieważ występuje w nim czasownik odnoszący się do procesu poznawczego, natomiast $w$ polskich tłumaczeniach rola człowieka ukazana jest jako mniej wyrazista $z$ uwagi na niementalny charakter użytych czasowników.

$\mathrm{Na}$ koniec rozważmy jeszcze jeden przykład ilustrujący przesunięcie w zakresie subiektywności, który ma jednocześnie związek z punktem widzenia w domenie oceny epistemicznej:

PRZYKŁAD 20

Steps to assess and intervene thoughtfully to maximize self-efficacy beliefs are likely to impact arthritis disability outcomes quite favorably and significantly, regardless of disease type, duration, or sociodemographic factors. 
(T3)

[...] mogą korzystnie i znacząco wpłynąć $[\ldots]$

(T4)

[...] często mają istotny korzystny wpływ na [...]

W przedstawionym powyżej fragmencie angielskiego tekstu źródłowego formułowana jest teza o pozytywnym wpływie określonych działań na przebieg niepełnosprawności u osób z zapaleniem stawów, przy czym teza ta opatrzona jest jednocześnie oceną stopnia pewności autora tekstu: are likely to impact („prawdopodobnie wpływają”). Zauważmy jednak, że dokonując oceny epistemicznej portretowanych treści, konceptualizator przestaje odgrywać rolę niezaangażowanego, zdystansowanego obserwatora, a wyrażony w ten sposób w tekście punkt widzenia wskazuje na jego obecność. Oznacza to, że konceptualizator konstruowany jest w tym przypadku w sposób znacznie zobiektyfikowany. Ten sposób konstrukcji sceny zachowany jest w większości przeanalizowanych tłumaczeń, np. w (T3), gdzie czasownik modalny „mogą” sygnalizuje punkt widzenia konceptualizatora. Tłumaczenie (T4) odnosi się natomiast jedynie do frekwencji występowania wpływu opisywanego przez omawianą tezę („często mają [...] wpływ”), a tym samym nie implikuje już punktu widzenia konceptualizatora. Można nawet stwierdzić, że ponieważ częstość występowania określonego zjawiska jest informacją obiektywną, niezależną od obserwatora, przekład ten nie opisuje już formułowanej przez autora tekstu tezy, lecz niezależną od niego informację o pewnym, odnotowanym fakcie. Tym samym przekład (T4) ilustruje przesunięcie w zakresie wymiaru subiektywności ze zobiektyfikowanego na subiektywny ogląd sceny.

\section{Wyniki i wnioski}

Wśród 229 przykładów poddanych analizie odnotowano 85 przypadków, w których w co najmniej jednym z pięciu tłumaczeń określona scena pojęciowa została skonstruowana inaczej niż w tekście źródłowym. Całkowita liczba przesunięć semantycznych odnotowanych w badanym materiale wyniosła 227, przy czym liczba zmian obrazowania w poszczególnych tłumaczeniach przedstawia się następująco: (T1): 35, (T2): 45, (T3): 62, (T4): 
54, (T5): 31, czyli średnio 45,4 zmiany w zakresie subiektywnych aspektów znaczenia $\mathrm{w}$ jednym tłumaczeniu. Należy jednocześnie przypomnieć, że analiza nie uwzględniała materiału językowego zawartego w tabelach oraz podpisach tabel i rysunków, a także tych fragmentów przekładów, które należało uznać za błąd tłumaczeniowy. Co więcej, pominięto również kilkanaście przykładów budzących wątpliwości co do natury ilustrowanych przez nie zmian semantycznych.

Jeśli chodzi o poszczególne wymiary obrazowania, zidentyfikowano następującą liczbę zmian: poziom abstrakcji/uszczegółowienia - 63; selekcja/ wyrazistość - 41; punkt widzenia - 84; subiektywność/obiektywność - 39 . Pomimo że badania zostały przeprowadzone na materiale składającym się z jednego tylko tekstu źródłowego (reprezentującego jedną dziedzinę) i jego pięciu tłumaczeń, w związku z czym na podstawie tak ograniczonej próbki materiału trudno formułować jakiekolwiek wnioski ogólne, uwagę zwracają niewątpliwie dwa najbardziej liczne zjawiska: zmiany semantyczne w zakresie poziomu szczegółowości oraz przesunięcia punktu widzenia. W pierwszym przypadku większość zmian (52 z 63) stanowią przykłady uogólnienia $\mathrm{w}$ stosunku do tekstu źródłowego, natomiast zmiany punktu widzenia występowały najczęściej w domenie epistemicznej ( 67 z 84). Wyniki te mogą wskazywać, z jednej strony, na dość częste stosowanie techniki uogólnienia, w wyniku czego potencjalnie istotne detale semantyczne nie docierają do odbiorcy tłumaczenia - co stoi w sprzeczności z kojarzoną zwykle z tekstami naukowymi precyzją opisu. Z drugiej strony, zaskakiwać mogą również dość liczne zmiany w zakresie oceny stopnia prawdziwości formułowanych tez - innego istotnego elementu dyskursu naukowego (por. Hyland 2005: 175). Co ciekawe, uzyskane wyniki (zob. przykłady 13 i 14) zdają się pokrywać z ustaleniami Agnes Pisanski-Peterlin (2010: 179), która zaobserwowała większy stopień pewności w analizowanych przez nią tłumaczeniach w porównaniu $\mathrm{z}$ tekstami oryginalnymi, które były pod tym względem bardziej ostrożne.

Jak pokazują niektóre przykłady, przyczyną zmian w obrazowaniu bywają niekiedy różnice systemowe między językiem źródłowym i docelowym - jak w przykładzie 5, gdzie niemożliwość użycia podobnie skondensowanej i semantycznie niekompozycyjnej konstrukcji w języku polskim wymusiła na wszystkich tłumaczach zastosowanie ekwiwalentu uszczegóławiającego tekst źródłowy; w przykładzie 10, w którym zachowanie tego samego punktu widzenia i dystansu między konceptualizatorem a obserwowaną przez niego 
sceną wymagałoby użycia rozbudowanego i stylistycznie nacechowanego ekwiwalentu opisowego; czy nawet w przykładzie 13, gdzie występujący w angielskim tekście źródłowym przysłówek arguably także nie ma w języku polskim równie zwięzłego, a jednocześnie równie pojemnego semantycznie odpowiednika i w związku z tym tłumacz musi wybierać pomiędzy użyciem nacechowanego stylistycznie dłuższego ekwiwalentu opisowego a mniejszym lub większym przesunięciem punktu widzenia $\mathrm{w}$ domenie stopnia pewności co do prawdziwości formułowanej tezy. Jednakże większość zidentyfikowanych w badanym materiale przypadków braku ekwiwalencji na poziomie obrazowania, jak również większość przykładów przedstawionych w poprzedniej części niniejszej pracy pokazuje, że znaczna część zmian w zakresie subiektywnych aspektów znaczenia wynika z nieumotywowanych i nieobiektywnych decyzji tłumacza (por. Levý 2009). Oczywiście niektóre $\mathrm{z}$ odnotowanych zmian translatorskich w stosunku do tekstu źródłowego można by uznać za mało istotne semantyczne „detale” (por. Tabakowska 2001: 98), jednakże inne, zwłaszcza znaczne przesunięcia w zakresie oceny epistemicznej (jak te w przykładach 11-15) czy daleko idące zmiany w zakresie - istotnej z punktu widzenia sukcesu aktu komunikacji naukowej szczegółowości (jak w przykładzie 3) bez wątpienia potwierdzają zasadność badania przekładu naukowego pod kątem subiektywnych aspektów znaczenia.

Jeśli chodzi o przedstawione powyżej wyniki liczbowe, należy je traktować z ostrożnością nie tylko dlatego, że analiza miała charakter wstępny i obejmowała miniaturową próbkę materiału. Jak pokazują przykłady 8,18 i 19, w niektórych przypadkach daną różnicę w zakresie subiektywnych aspektów znaczenia można rozpatrywać w kategoriach kilku wymiarów obrazowania. Takie przypadki wskazują na wielowymiarowość oraz wzajemne powiązanie różnych aspektów znaczenia subiektywnego, wyróżniane zaś w gramatyce kognitywnej poszczególne wymiary obrazowania nie stanowią „autonomicznych” parametrów opisujących niezależne od siebie właściwości struktury semantycznej. W fakcie tym nie należy bynajmniej upatrywać metodologicznej ułomności modelu Langackera, a wręcz przeciwnie: skoro zmiana w obrębie jednego z wymiarów obrazowania (np. selekcji czy punktu widzenia) może pociągać za sobą przesunięcia w zakresie innego (np. subiektywności/obiektywności), oznacza to, że aparat pojęciowy gramatyki kognitywnej jest, jako narzędzie analityczne, tym bardziej czuły na rozmaite detale semantyczne. 


\section{Podsumowanie}

Celem przedstawionych badań było rzucenie światła na charakter zmian w zakresie subiektywnych aspektów znaczenia, jakie mogą występować w procesie międzyjęzykowego przekładu tekstów naukowych. Uzyskane wyniki potwierdzają hipotezę, że tłumaczenia tego samego tekstu naukowego wykonane przez różnych tłumaczy różnią się od siebie w zakresie subiektywnych aspektów znaczenia ujmowanych przez Langackerowskie wymiary obrazowania. Różnice między poszczególnymi tłumaczeniami tego samego tekstu źródłowego wskazują z kolei, że nawet tekst naukowy - kojarzony tradycyjnie z takimi cechami jak obiektywność, skupienie na faktach i precyzja opisu - jest podatny na występujące w procesie przekładu przesunięcia semantyczne wynikające nie tylko z różnic między językami, ale również z tego, że podmiotem dokonującym przekładu jest człowiek.

Ogólnie rzecz ujmując, obiektywne cechy danej sytuacji pozajęzykowej, do której odnosi się wypowiedź językowa, nie przekładają się automatycznie na określony wybór tego czy innego sposobu jej językowego opisu (Langacker 2002: 214). Tekst naukowy nie jest pod tym względem wyjątkiem: wbrew powszechnym mniemaniom proza naukowa nie stanowi obiektywnej relacji dotyczącej prawd i faktów, lecz relację oddającą sposób widzenia tych faktów przez konkretnego człowieka - relację, której znaczną część stanowią elementy odnoszące się bezpośrednio lub pośrednio do tworzącego ją podmiotu, któremu przyświecają określone cele komunikacyjne, takie jak choćby przekonanie czytelnika do formułowanych tez. Co więcej, odnotowuje się jednocześnie postępującą subiektywizację dyskursu naukowego (Witosz 2012). Fakt ten potwierdza zresztą od dawna stawianą przez kognitywistów tezę, że nie istnieje ostra linia demarkacyjna między literaturą piękną a innymi przykładami użycia języka (Tabakowska 2001: 24), a w związku z tym różnica między prozą literacką i prozą naukową jest również „kwestią stopnia”. Wobec tego zjawiska odnotowane w przedstawionych badaniach wstępnych skłaniają do wniosku, że ekwiwalencja na poziomie subiektywnych aspektów znaczenia powinna stać się jednym z kryteriów oceny przekładu naukowego (por. Tabakowska 2001: 167), a Langackerowskie wymiary obrazowania stanowią użyteczne narzędzie analityczne w tym zakresie. 


\section{Źródła}

Marks R., 2014, Self-efficacy and arthritis disability: An updated synthesis of the evidence base and its relevance to optimal patient care. „Health Psychology Open", 1(1).

\section{Literatura}

Baker M., 1992, In Other Words: A coursebook on translation, London-New York. Bedyńska S., Brzezicka A., Cypryańska M., 2013, Od teorii do analizy statystycznej. Jak badać zjawiska psychologiczne?, [w:] Statystyczny drogowskaz 1. Praktyczne wprowadzenie do wnioskowania statystycznego, t. 1, S. Bedyńska, M. Cypryańska (red.), Warszawa, s. 17-45.

Bühler A., 2002, Translation as interpretation, [w:] Translation Studies: Perspectives on the Emerging Discipline, A. Riccardi (red.), Cambridge-New York, s. 56-74.

Croft W., Crurse D.A., 2004, Cognitive Linguistics, Cambridge-New York.

Cuyckens H., Geeraerts D., 2007, Introducing Cognitive Linguistics, [w:] The Oxford Handbook of Cognitive Linguistics, D. Geeraerts, H. Cuyckens (red.), Oxford-New York, s. 3-21.

Duszak A., 1994, Academic discourse and intellectual styles, ,Journal of Pragmatics”, 21(3), s. 291-313.

Gajda S., 1982, Podstawy badań stylistycznych nad językiem naukowym, Warszawa.

Gray B., Biber D., 2012, Current conceptions of stance, [w:] Stance and Voice in Written Academic Genres, K. Hyland, C. Sancho Guinda (red.), BasingstokeNew York, s. 15-33.

Hyland K., 1998, Hedging in Scientific Research Articles, Amsterdam-Philadelphia. Hyland K., 2005, Stance and Engagement: a Model of Interaction in Academic Discourse, „Discourse Studies”, 7(2), s. 173-192.

Hyland K., 2014, Disciplinary discourses: writer stance in research articles, [w:] Writing: Texts, Processes and Practices, Ch.N. Candlin, K. Hyland (red.), London-New York, s. 99-121.

Johnson M., 1987, The Body in the Mind. The Bodily Basis of Meaning, Imagination, and Reason, Chicago-London.

Kozłowska Z., 2007, O przekładzie tekstu naukowego (na materiale tekstów językoznawczych), wyd. 2, Warszawa.

Kiklewicz A., 2008, Ambisemia jako kategoria semantyki funkcjonalnej, „Biuletyn Polskiego Towarzystwa Językoznawczego", z. 64, s. 63-75. 
Lakoff G., 1991, Cognitive versus generative linguistics: How commitments influence results, „Language \& Communication”, 11(1/2), s. 53-62.

Lakoff G., 2011 [1987], Kobiety, ogień i rzeczy niebezpieczne. Co kategorie mówią nam o umyśle, Kraków.

Langacker R.W., 1987, Foundations of Cognitive Grammar, Vol. 1: Theoretical Prerequisites, Stanford.

Langacker R.W., 2002 [1991], Concept, Image, and Symbol. The Cognitive Basis of Grammar, 2nd edition, Berlin-New York.

Langacker R.W., 2005, Obserwacje i rozważania na temat zjawiska subiektyfikacji, Kraków.

Langacker R.W., 2009, Gramatyka kognitywna. Wprowadzenie, Kraków.

Levý J., 2009 [1967], Przekład jako proces podejmowania decyzji, [w:] Współczesne teorie przekładu, P. Bukowski, M. Heydel (red.), Kraków, s. 71-86.

Malmkjaer K., 1998, Love thy Neighbour: Will Parallel Corpora Endear Linguists to Translators?, „Meta”, 43(4), s. 534-541.

Pisanski Peterlin A., 2010, Hedging Devices in Slovene-English Translation: A Corpus-Based Study, „Nordic Journal of English Studies”, 9(2), s. 171-193.

Schank R.C., Abelson R.P., 1977, Scripts, plans, goals, and understanding, Hillsdale.

Sedgley T., 2013, The responsibilities of being a physiotherapist, [w:] Tidy's Physiotherapy, 15th edition, S.B. Porter (red.), Edinburgh-New York, s. 1-21.

Silver M., 2003, The Stance of Stance: a Critical Look at Ways Stance Is Expressed and Modeled in Academic Discourse, ,Journal of English for Academic Purposes”, 2(4), s. 359-374.

Tabakowska E., 2001 [1993], Językoznawstwo kognitywne a poetyka przekładu, Kraków.

Tabakowska E., 2004, O językowych wyznacznikach punktu widzenia, [w:] Punkt widzenia w języku i w kulturze, J. Bartmiński, S. Niebrzegowska-Bartmińska, R. Nycz (red.), Lublin.

Vinay J.-P., Darbelnet J., 1957, Stylistique comparée du français et de l'anglais, Paris. Witosz B., 2012, Naukowy język polski wobec metodologii ponowoczesnej, [w:] Oblicza polszczyzny, A. Markowski, R. Pawelec (red.), Warszawa, s. 241-252. 


\section{Scientific translation and imagery: a pilot study into subjective aspects of meaning in academic prose based on the use of several translations of a single source text}

\section{Summary}

Scientific - and, more broadly, academic - discourse is often associated with impersonality, objectivity and a focus on facts. However, over the last two decades or so more and more linguistic studies have shown that it includes numerous linguistic elements that express the author's subjective assessment of, attitude to or viewpoint on facts and scientific findings, the use of which is aimed at increasing the persuasiveness of the text. Therefore, it seems reasonable to enquire into what happens to the subjective elements of an academic text in translation, especially in view of the fact that translations ultimately express translators' own interpretations, or conceptualizations, of the source text which may also be influenced by subjective factors, such as one's personal knowledge, beliefs, cognitive abilities and experience. This paper presents a pilot study on subjective aspects of meaning in the translation of an academic text, based on the use of a miniature one-to-many parallel corpus consisting of a single English source text and its five Polish translations. The basic assumption behind this methodology is that multiple translations of the same source text produced by different translators should express the same "objective" content, which may, however, be construed differently as a result of shifts in the subjective aspects of meaning. A semantic analysis in terms of Ronald Langacker's dimensions of imagery (aka focal adjustments) - so far mainly used to examine semantic "minutiae" in literary texts - bears out the hypothesis and casts some interesting light on the nature of the semantic shifts in question. Given the role of translation in the dissemination of knowledge and the important function of the subjective elements of an academic text, it is suggested that it is worth applying the concept of equivalence at the level of imagery in studies of the translation of academic prose.

Keywords: translation of academic prose, academic text, cognitive grammar, imagery

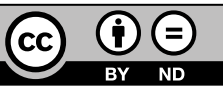

